\section{Social deterministic factors to participation in the National Health Insurance Scheme in the context of rural Ghanaian setting}

\author{
Stephen Manortey, ${ }^{1}$ Steve Alder, ${ }^{1}$ \\ Benjamin Crookston, ${ }^{2}$ Ty Dickerson, ${ }^{3}$ \\ James VanDerslice, ${ }^{1}$ Scott Benson ${ }^{1}$ \\ ${ }^{1}$ Department of Family and Preventive \\ Medicine, University of Utah, Salt Lake \\ City; ${ }^{2}$ Department of Health Sciences, \\ Brigham Young University, Provo; \\ ${ }^{3}$ Department of Pediatrics, University \\ of Utah, Salt Lake City, USA
}

\section{Abstract}

The primary purpose of this study is to identify predictors of complete household enrollment into the National Health Insurance Scheme (NHIS) among inhabitants of the Barekese sub-district in the Ashanti Region of Ghana. Heads of households in 20 communities from the Barekuma Collaborative Community Project site were interviewed to gather data on demographic, socioeconomic status (SES) indicators and complete household subscription in the NHIS. Logistic regression model was used to predict enrollment in the NHIS. Of the 3228 heads of households interviewed, 60 percent reported having all members of their respective households enrolled in the NHIS. Residents in the classified Middle and High SES brackets had 1.47 (95\% CI: 1.21-1.77) and 1.66 (95\% CI: 1.272.16) times higher odds, respectively, of complete household enrollment compared to their counterparts in the Low SES category. The odds of enrolling in the program tend to increase progressively with the highest level of education attained by the head of the family unit. Eight years after the introduction of the national health insurance policy in Ghana, the reported subscription rate for complete households was about 60 percent in the 20 rural communities that participated in the study. This finding calls for the need to step up further national strategies that will help increase enrollment coverage, especially among the poor and less educated in the rural communities.

\section{Introduction}

Health insurance, based on resource pooling, has gained considerable favor in recent years as an effective tool for improving access to healthcare services among low-income and resource challenged countries around the globe, including Ghana. ${ }^{1,2}$ Motivating this is the fact that many national policy decisions are being aligned with the goal of making healthcare services universally available as a component of poverty reduction. ${ }^{3}$

Ghana has adopted several strategies in the past in efforts to make quality basic healthcare services available to its citizens. These included offering free healthcare services in all government owned health facilities soon after gaining independence in $1957 .{ }^{4}$ Through the 1980 s and early 1990s, Ghana's population increased while several economic challenges emerged, thereby making it difficult for the then government to financially support such a system.

In response to these circumstances, a nationwide hospital user fee policy, famously known as the cash-and-carry program, was implemented to supplement the revenue of the healthcare system. Under this policy, patients and their families were made to share the cost for most prescribed health services and fully pay for all medications at the point of service delivery. ${ }^{5-7}$ Empirical studies have documented the detrimental impact this program had on healthcare seeking behaviors of most Ghanaians, especially the majority who are unable to afford the high costs for healthcare services. ${ }^{8}$ The consequential effects on the larger society included promoting the use of unorthodox drugs, delayed reporting to legitimate health facilities for treatment until their conditions had advanced, leading to delayed treatment, increased severity of disease, higher costs and higher mortality. ${ }^{8-10}$

In an attempt to address these issues, Ghana adopted the Community Based Health Insurance (CBHI) scheme; ${ }^{11}$ a program typically managed by contributing members, including setting and collecting premiums, negotiating benefits packages, etc. After several years of piloting the $\mathrm{CBHI}$ program in selected districts, ${ }^{12,13}$ the 2003 Parliament promulgated the National Health Insurance Act 650 and a subsequent Legislative Instrument (LI 1809) in 2004 leading to the implementation of the National Health Insurance Scheme (NHIS) in 2005 as a nationalized health insurance program to help the citizenry gain more affordable access to health care services. ${ }^{4}$ Membership into the scheme is based on annual minimum premium of about 8 Ghana cedis $(\mathrm{GHC})$ for individuals between the ages 18 and 70 years. Individuals outside this age bracket including those identified as indigents are however exempted from fee payments. Ghana, to a very large extent is recognized as a global leader in implementing nationalized health insurance in Sub-Saharan Africa and is currently striving for universal coverage among her citizens. ${ }^{14}$
Correspondence: Stephen Manortey, Department of Family and Preventive Medicine, University of Utah, 375 Chipeta Way, Suite A, Salt Lake City, Utah 84108 , USA.

Tel. +1.801.5873321 - Fax: +1.801 .5873353 .

E-mail: steve.manortey@utah.edu

Key words: National Health Insurance Scheme, Barekese sub-district, access to healthcare, Barekuma Collaborative Community Project, Ghana.

Acknowledgements: we want to acknowledge the staff of the Research and Development Unit of the Komfo Anokye Teaching Hospital in Kumasi (Ghana) and the BCCDP fieldworkers who helped in the data collection process.

Contributions: SM, SA, BC, TD, JV and SB design the research methodology; SM collected and analyzed the data; SM, SA, BC, TD, JV and SB wrote the manuscript. SM has the primary responsibility for its final content. All authors read and approved the final manuscript.

Conflict of interests: the authors report no conflict of interests.

Received for publication: 26 June 2013.

Revision received: 6 February 2014.

Accepted for publication: 6 February 2014.

This work is licensed under a Creative Commons Attribution NonCommercial 3.0 License (CC BYNC 3.0).

(C) Copyright S. Manortey et al., 2014

Licensee PAGEPress, Italy

Journal of Public Health in Africa 2014; 5:352

doi:10.4081/jphia.2014.352

The NHIS was reported to have been instrumental in extending health insurance coverage to most residents with the cumulative membership of the scheme increasing from 1.3 million in 2005 to 18 million in $2010 .^{15}$ In spite of this impressive progress, findings from recent studies show the NHIS is falling short of its equity goals, with lower enrollment among the poor, a majority of whom reside in the rural areas. ${ }^{4,16,17}$ Further, in a 1995 study, Gilson et al. reported that identifying the very poor, classified as indigents, who are exempted from paying premiums was becoming problematic because of the seasonal and annual variations in household income and living conditions. ${ }^{18}$ To help address these challenges, Aikins et al. recommended that the poor in Ghana be identified using area specific constructs that account for important local differences (e.g., needs of the rural poor compared to the urban poor) (Aikins M, Dzikunu $\mathrm{H}$ Utilization by and cost of health care of the insured poor in Saboba-Chereponi District Northern Region-Danida Health Sector 
Support Office. Unpublished Thesis, 2006). Such studies will help gain insights into the successes and challenges of the NHIS and will inform policy decisions aimed at promoting subscription to the scheme.

The primary purpose of this study therefore is to evaluate the socio-economic factors that predict an entire household subscription to the NHIS among residents in the Barekuma Collaborative Community Development Project (BCCDP) site.

\section{Materials and Methods}

In July 2011, a cross-sectional study was conducted in 20 communities that constitute the BCCDP research site to evaluate the relationships between socioeconomic and demographic factors on household subscription to the NHIS. The BCCDP site is located about 25 kilometers north-west of Kumasi in the Barekese sub-district of the AtwimaNwabiagya district of Ghana and consist of approximately 18,500 people in a typical rural and peri-urban settings, with individual com- munities ranging from few hundred to over 4000 inhabitants.

The BCCDP is a collaborative partnership grounded on the principles of Community Based Participatory Research (CBPR) ${ }^{19}$ among the leadership of the respective communities, researchers and health professionals from Komfo Anokye Teaching Hospital (KATH) and the Kwame Nkrumah University of Science and Technology (KNUST), both in Kumasi, Ghana, and the University of Utah (UofU) in Salt Lake City, USA. Over the past 10 years, stakeholders from the BCCDP have worked to address several health concerns to the communities and other partners such as sanitation, malaria, diarrhea, schistosomiasis, nutrition and reproductive health. ${ }^{20-22}$

Approximately 3228 household heads in the study region were interviewed on questions related to subscription to the NHIS, socioeconomic variables (such as ownership of farmland, home, household items, etc.) and demographic variables (such as sex, age, marital status, level of education, religious beliefs, occupation, etc.). Most interviews were conducted in Twi, which is the local language for this area.
Table 1. Distribution of respondents' demographic characteristics.

\begin{tabular}{|c|c|c|}
\hline Variable & Categories & N (\%) \\
\hline Sex & $\begin{array}{l}\text { Female } \\
\text { Male }\end{array}$ & $\begin{array}{l}1141(35.35) \\
2087(64.65)\end{array}$ \\
\hline Age (years) & $\begin{array}{l}\leq 35 \\
36-45 \\
46-60 \\
\geq 61\end{array}$ & $\begin{array}{l}796(25.56) \\
800(25.69) \\
817(26.24) \\
701(22.51)\end{array}$ \\
\hline Marital status & $\begin{array}{l}\text { Married } \\
\text { Single } \\
\text { Divorced } \\
\text { Widowed }\end{array}$ & $\begin{array}{l}2340(72.49) \\
231(7.16) \\
263(8.15) \\
394(12.21)\end{array}$ \\
\hline Occupation & $\begin{array}{l}\text { Farming } \\
\text { Teachers/Students } \\
\text { Trading } \\
\text { Others }\end{array}$ & $\begin{array}{c}1489(46.13) \\
111(3.44) \\
596(18.46) \\
1032(31.97)\end{array}$ \\
\hline Educational level & $\begin{array}{l}\text { None } \\
\text { Primary } \\
\text { Middle/Junior High } \\
\text { Senior High } \\
\text { Tertiary }\end{array}$ & $\begin{array}{c}1085(33.61) \\
425(13.17) \\
1353(41.91) \\
200(6.20) \\
165(5.11)\end{array}$ \\
\hline Religious beliefs & $\begin{array}{l}\text { Christianity } \\
\text { Moslem } \\
\text { Others }\end{array}$ & $\begin{array}{c}2548(78.93) \\
576(17.84) \\
104(3.22)\end{array}$ \\
\hline Household size & $\begin{array}{l}\leq 4 \\
5-8 \\
9-11 \\
\geq 12\end{array}$ & $\begin{array}{l}1309(40.55) \\
1394(43.18) \\
277(8.58) \\
248(7.68)\end{array}$ \\
\hline SES & $\begin{array}{l}\text { Low } \\
\text { Middle } \\
\text { High }\end{array}$ & $\begin{array}{c}1874(58.05) \\
935(28.97) \\
419(12.98) \\
\end{array}$ \\
\hline NHIS enrollment & $\begin{array}{l}\text { Yes } \\
\text { No } \\
\end{array}$ & $\begin{array}{l}1952(60.47) \\
1276(39.53)\end{array}$ \\
\hline
\end{tabular}

SES, socioeconomic status; NHIS, National Health Insurance Scheme.
Only respondents clearly identified as heads of households, living in the participating communities with their families and provided informed consents were included in the study. The response rate was approximately 95 percent with the absence of the head of the household after persistent effort to contact him or her being the primary reason for non-participation. The study received ethical approval from the UofU Institutional Review Board and the Committees on Human Research Publications and Ethics of the KNUST College of Health Sciences, School of Medical Sciences.

All analyses were conducted using STATA statistical software package (StataCorp. 2007. Stata Statistical Software: Release 12. StataCorp LP, College Station, TX, USA). A univariate analysis of selected variables was conducted to calculate summary statistics. Complete household subscription to the NHIS was used as the outcome variable for logistic regression modeling based on the research question, Is everyone in your household a registered member of the NHIS?

Given the difficulties in the collection of income and expenditure data to determine the socioeconomic status (SES) of the households, we developed a scale by assessing ownership of fourteen household assets with weighting of each of these items based on factor scores from principal component analysis (PCA). ${ }^{23,24}$ Variables with low standard deviations tend to carry low weights, such that items that were routinely present or absent had less influence on differentiating SES among households. ${ }^{25}$ Each household was assigned an aggregate SES scores. The ranked scores were then classified into three SES groups as Low, Middle

Table 2. Scoring weights derived from principal component analysis.

\begin{tabular}{lcccc}
\hline $\begin{array}{l}\text { Household } \\
\text { item }\end{array}$ & Component 1 & $\begin{array}{c}\text { Unexplained } \\
\text { variance }\end{array}$ & Mean & SD \\
Electricity & 0.3631 & 0.5129 & 0.5139 & 0.4999 \\
Fan & 0.3953 & 0.4227 & 0.2385 & 0.4263 \\
\hline Furniture & 0.3037 & 0.6593 & 0.6391 & 0.4803 \\
Radio & 0.3173 & 0.6281 & 0.5638 & 0.4960 \\
\hline Television & 0.4015 & 0.4045 & 0.3866 & 0.4871 \\
Refrigerator & 0.3586 & 0.5249 & 0.1568 & 0.3636 \\
\hline Cell Phone & 0.3192 & 0.6236 & 0.7063 & 0.4555 \\
Computer & 0.2208 & 0.8200 & 0.0403 & 0.1966 \\
\hline Motorcycle & 0.0958 & 0.9661 & 0.0229 & 0.1497 \\
Car & 0.1754 & 0.8864 & 0.0325 & 0.1774 \\
\hline Tractor & 0.0082 & 0.9998 & 0.0015 & 0.0393 \\
Camera & 0.1260 & 0.9414 & 0.0115 & 0.1065 \\
\hline Sewing machine & 0.1498 & 0.9171 & 0.1090 & 0.3117 \\
Generator & 0.0170 & 0.9989 & 0.0198 & 0.1394 \\
\hline
\end{tabular}


and High. Travel cost from individual homes to the designated registration center (Nkawie) to enroll in the NHIS were estimated taking into consideration both travel on foot from the home to a centralized point in the respective communities and the cost for travelling with public transport. Cut-off points used in creating categories for all numeric categorical indicators (such as total travel time and cost, age, household size, etc.) were selected based on the observed distribution patterns of the variables. Bivariate analyses were used to establish associations among the SES groupings and selected demographic variables using Fisher's Exact or Pearson tests. Multivariate logistic regression was used to create a statistical model to predict household subscription to the NHIS controlling for SES and other demographic variables.

\section{Results}

Of the 3228 heads of households that participated in the survey, 2087 (65\%) were males while the remaining 1141 (35\%) were females. Assessment of NHIS enrollment revealed that 40 percent of households did not have health insurance coverage for all household members. About a third of the respondents reported not having any form of formal education. Of the total study participants, 1489 (46\%) reported farming as their main occupation while 111 (3\%) reported being teachers or students at higher educational institutions at the time of the interview. Classification by religious beliefs revealed that 2548 (79\%) were Christians while the rest professed faith in other practices, such as Islamic or African traditional religion (Table 1).

The results in Table 2 show the means, standard deviations and factor scores derived for each household asset in the first linear component from the PCA. Since the code for response to ownership of an item was binary, a higher mean value indicates more homes owned such assets.

Bivariate analyses to measure the relationships among selected variables (such as sex, age, marital status, educational level, religious affiliation, occupation etc.) with SES indicated statistically significant associations (Table 3). Similarly, results between complete household subscription into the NHIS on unadjusted indicators, (such as occupation, educational level, household size, travel cost, and SES) showed significant statistical associations (Table 4).

Using findings from the bivariate analyses, a multivariate logistic regression model was constructed to predict complete household enrollment into the NHIS. Complete household subscription into the NHIS tends to increase with the age of the head of household; with respondents aged 61 years and above having 1.87 (95\% CI: 1.44-2.14) times the odds of enrolling their dependents compared to their counterparts aged 35 years and below. Similar findings were detected with the highest level of education attained by the responding heads of households; where those with a tertiary level of education having 2.14 (95\% CI: 1.31-3.51) times the odds of enrolling their dependents into the insurance scheme compared to their counterparts that have no formal education.

The odds of subscribing to the NHIS tend to diminish with an increase in household size and the cost of travel to the registration center. Households with more than 12 members had 0.67 (95\% CI: $0.24-0.45)$ times the odds of enrolling all members compared to those with less than 4 memberships. Households that spend more than $7.60 \mathrm{GHC}$ on a round way trip to the registration center had $0.59(95 \% \mathrm{CI}$ :
0.28-0.58) times the odds of enrolling all members compared to those that spend less than $3.90 \mathrm{GHC}$.

\section{Discussion}

Pooling resources to help mitigate and share the financial risk of health care is considered to have great potential for promoting efficient health delivery system in the economic challenged countries around the globe. ${ }^{26}$ It is an effective way of removing the impact of excessive health expenditures on the poor, and facilitating increases in health resource availability.

Comparing hospital utilization rates during the cash and carry regime in Ghana to what now prevails after the inception of the NHIS,

Table 3. Bivariate analysis of selected indicators on socioeconomic status.

\begin{tabular}{|c|c|c|c|c|}
\hline Indicators & & hold SES (N= & & P-value \\
\hline & $\begin{array}{c}\text { Low } \\
\mathrm{N}=1874(\%)\end{array}$ & $\begin{array}{c}\text { Middle } \\
\text { N=935 (\%) }\end{array}$ & $\begin{array}{c}\text { High } \\
\mathrm{N}=419(\%)\end{array}$ & \\
\hline Sex & & & & $<0.001$ \\
\hline Female & $717(38.26)$ & $319(34.12)$ & $105(25.06)$ & \\
\hline Male & $1157(61.74)$ & $616(65.88)$ & $314(74.94)$ & \\
\hline Age (years) & & & & 0.002 \\
\hline$\leq 35$ & $425(23.72)$ & $261(28.71)$ & $110(26.63)$ & \\
\hline $36-45$ & 441 (24.61) & $253(27.83)$ & $106(25.67)$ & \\
\hline $46-60$ & $484(27.01)$ & $216(23.76)$ & $117(28.33)$ & \\
\hline$\geq 61$ & $442(24.67)$ & $179(19.69)$ & 80 (19.37) & \\
\hline Marital status & & & & $<0.001$ \\
\hline Married & $1314(70.12)$ & $696(74.44)$ & $330(78.76)$ & \\
\hline Single & $121(6.46)$ & $80(8.56)$ & $30(7.16)$ & \\
\hline Divorced & $174(9.28)$ & $61(6.52)$ & $28(6.68)$ & \\
\hline Widowed & 265 (14.14) & $98(10.48)$ & $31(7.40)$ & \\
\hline Occupation & & & & $<0.001$ \\
\hline Farming & 1096 (58.48) & 303 (32.41) & 90 (21.48) & \\
\hline Teachers/Students & $31(1.65)$ & $44(4.71)$ & $36(8.59)$ & \\
\hline Trading & $304(16.22)$ & $205(21.93)$ & $87(20.76)$ & \\
\hline Others & $443(23.64)$ & $383(40.96)$ & $206(49.16)$ & \\
\hline Educational level & & & & $<0.001$ \\
\hline None & 738 (39.38) & $271(28.98)$ & 76 (18.14) & \\
\hline Primary & $263(14.03)$ & $116(12.41)$ & $46(10.98)$ & \\
\hline Middle/Junior High & $744(39.70)$ & $424(45.35)$ & $185(44.15)$ & \\
\hline Senior High & $86(4.59)$ & $69(7.38)$ & $45(10.74)$ & \\
\hline Tertiary Education & $43(2.29)$ & $55(5.88)$ & $67(15.99)$ & \\
\hline Religious belief & & & & 0.004 \\
\hline Christianity & $1500(80.04)$ & $711(76.04)$ & 337 (80.43) & \\
\hline Moslem & 308 (16.44) & $202(21.60)$ & $66(15.75)$ & \\
\hline Others & $66(3.52)$ & $22(2.35)$ & $16(3.82)$ & \\
\hline Household size & & & & 0.840 \\
\hline$\leq 4$ & 775 (41.36) & $376(40.21)$ & 158 (37.71) & \\
\hline 5-8 & 801 (42.74) & 407 (43.53) & $186(44.39)$ & \\
\hline $9-11$ & $160(8.54)$ & $80(8.56)$ & $37(8.83)$ & \\
\hline$\geq 12$ & $138(7.36)$ & $72(7.70)$ & $38(9.07)$ & \\
\hline Travel cost* & & & & $<0.001$ \\
\hline$\leq 3.90 \mathrm{GHC}$ & 889 (47.44) & $849(90.80)$ & 413 (98.57) & \\
\hline 4.00-7.50 GHC & $812(43.33)$ & $76(8.13)$ & $6(1.43)$ & \\
\hline$\geq 7.60 \mathrm{GHC}$ & $173(9.23)$ & $10(1.07)$ & $0(0.00)$ & \\
\hline
\end{tabular}

SES, socioeconomic status. ${ }^{*} 1 \mathrm{GH} \mathrm{c}=\$ 0.67$ as at the time of the study. 
suggests the latter is offering more equitable access to healthcare services. ${ }^{27}$ Despite Ghana's success in this effort to form and implement a nationalized health insurance policy, some challenges still undermine the policy objective of the NHIS for attaining nationwide coverage years after the introduction. ${ }^{28}$

Eight years after the implementation of the program, our study detected a complete household enrollment rate of about 60 percent among the residents of the Barekese subdistrict, which is a typical rural setting in the Ashanti region of Ghana. This is similar to the national enrolled figure in 2009 as quoted in the National Health Insurance Authority annual report. ${ }^{26}$ This study indicates that subsistence farmers who rely solely on the weather for successful harvests constitute about 46 percent of the total respondents. Thus, a failure in a season will challenge most residents, including leaving them incapable of affording the cost to enroll into the scheme. In contrast, it was shown that households headed by teach- ers or family heads enrolled in school had 1.66 (95\% CI: $0.93-2.95)$ times the odds of being more likely to enroll their dependents in the program compared to their farming counterparts. This could mean that teachers earned reliable monthly incomes and can afford registration at any time. Policy approach that specifically target farmers is therefore necessary to improve enrollment.

Further analysis of the data revealed a progressive likelihood for an entire household to enroll in the program given the level of formal education attained by the family head as compared to those with none. Household heads that had up to a tertiary level of education were more than twice as likely to subscribe to the program compared to their counterparts (about a third of the total respondents) who have no formal education.

Public misconception about features of health insurance schemes and the need to renew membership is a major weakness that potentially affects coverage and needs to be addressed. ${ }^{3}$ Insufficient knowledge on the schemes' benefits among residents in the subdistrict might have contributed significantly to the observed non-participation rate. Since the level of education attained was detected a significant determinant of enrollment, information on the scheme has to be disseminated in ways that it reaches those with less education to ensure that this segment of the population are not excluded. Information disseminating materials on subscription to the NHIS in mediums such as radio announcements and brochures must be translated into the various local languages to offer those without formal education the opportunity to gain better understanding of the program.

In spite of the already existing government effort to subsidize the annual premium and exempt identified indigents from payment, it is worth noting that there are always additional costs, including those associated with travel to a centralized location to enroll in the scheme. The inability to afford such cost deters a notable proportion of the populations, especially in the remote areas from participating in the NHIS. Depending on the geographi-

Table 4. Multivariate logistic analysis of household subscription to the National Health Insurance Scheme.

\begin{tabular}{|c|c|c|c|c|c|c|c|c|}
\hline Variable & Category* & No. $(\%)$ & Odds ratio & $\begin{array}{c}\text { P-value } \\
\text { (unadjusted) }\end{array}$ & (95\% CI) & $\begin{array}{l}\text { Odds ratio } \\
\text { (adjusted) }\end{array}$ & P-value & $(95 \% \mathrm{CI})$ \\
\hline Sex & $\begin{array}{l}\text { Female (R) } \\
\text { Male }\end{array}$ & $\begin{array}{l}1141(35.35) \\
2087(64.65)\end{array}$ & $\begin{array}{l}1.000 \\
0.939\end{array}$ & $\begin{array}{l}0.406 \\
0.406\end{array}$ & $\stackrel{-}{-}$ & $\begin{array}{l}1.000 \\
0.754\end{array}$ & 0.008 & $\begin{array}{c}- \\
0.61-0.93\end{array}$ \\
\hline Age (years) & $\begin{array}{l}\leq 35(\mathrm{R}) \\
36-45 \\
46-60 \\
\geq 61\end{array}$ & $\begin{array}{l}796(25.56) \\
800(25.69) \\
817(26.24) \\
701(22.51)\end{array}$ & $\begin{array}{l}1.000 \\
1.161 \\
1.111 \\
1.211\end{array}$ & $\begin{array}{l}0.292 \\
0.144 \\
0.298 \\
0.071\end{array}$ & $\begin{array}{c}- \\
0.95-1.42 \\
0.91-1.36 \\
0.98-1.49\end{array}$ & $\begin{array}{l}1.000 \\
1.307 \\
1.410 \\
1.866\end{array}$ & $\begin{array}{l}- \\
0.017 \\
0.003 \\
0.000\end{array}$ & $\begin{array}{c}- \\
1.05-1.63 \\
1.12-1.77 \\
1.44-2.14\end{array}$ \\
\hline Marital status & $\begin{array}{l}\text { Married (R) } \\
\text { Single } \\
\text { Divorced } \\
\text { Widowed }\end{array}$ & $\begin{array}{c}2340(72.49) \\
231(7.16) \\
263(8.15) \\
394(12.21)\end{array}$ & $\begin{array}{l}1.000 \\
0.843 \\
0.895 \\
1.046\end{array}$ & $\begin{array}{l}0.489 \\
0.219 \\
0.399 \\
0.686\end{array}$ & $\begin{array}{c}- \\
0.64-1.11 \\
0.69-1.16 \\
0.84-1.30\end{array}$ & $\begin{array}{l}1.000 \\
0.686 \\
0.807 \\
0.912\end{array}$ & $\begin{array}{l}- \\
0.017 \\
0.170 \\
0.536\end{array}$ & $\begin{array}{c}- \\
0.50-0.93 \\
0.59-1.10 \\
0.68-1.22\end{array}$ \\
\hline Occupation & $\begin{array}{l}\text { Farming (R) } \\
\text { Teachers/Students } \\
\text { Trading } \\
\text { Others }\end{array}$ & $\begin{array}{c}1489(46.13) \\
111(3.44) \\
596(18.46) \\
1032(31.97)\end{array}$ & $\begin{array}{l}1.000 \\
2.933 \\
1.344 \\
1.498\end{array}$ & $\begin{array}{c}<0.001 \\
0.000 \\
0.003 \\
0.000\end{array}$ & $\begin{array}{c}- \\
1.84-4.66 \\
1.11-1.63 \\
1.27-1.76\end{array}$ & $\begin{array}{l}1.000 \\
1.659 \\
1.046 \\
1.110\end{array}$ & $\begin{array}{l}- \\
0.085 \\
0.698 \\
0.297\end{array}$ & $\begin{array}{c}- \\
0.93-2.95 \\
0.83-1.32 \\
0.91-1.35\end{array}$ \\
\hline Educational level & $\begin{array}{l}\text { None (R) } \\
\text { Primary } \\
\text { Middle/JHS } \\
\text { SHS } \\
\text { Tertiary }\end{array}$ & $\begin{array}{c}1085(33.61) \\
425(13.17) \\
1353(41.91) \\
200(6.20) \\
165(5.11)\end{array}$ & $\begin{array}{l}1.000 \\
0.886 \\
1.246 \\
1.472 \\
3.153\end{array}$ & $\begin{array}{l}<0.001 \\
0.294 \\
0.008 \\
0.017 \\
0.000\end{array}$ & $\begin{array}{c}- \\
0.71-1.11 \\
1.06-1.47 \\
1.07-2.02 \\
2.10-4.72\end{array}$ & $\begin{array}{l}1.000 \\
0.991 \\
1.295 \\
1.501 \\
2.142\end{array}$ & $\begin{array}{c}- \\
0.941 \\
0.010 \\
0.024 \\
0.003\end{array}$ & $\begin{array}{c}- \\
0.77-1.27 \\
1.06-1.57 \\
1.06-2.13 \\
1.31-3.51\end{array}$ \\
\hline Religious beliefs & $\begin{array}{l}\text { Christianity (R) } \\
\text { Moslem } \\
\text { Others }\end{array}$ & $\begin{array}{c}2548(78.93) \\
576(17.84) \\
104(3.22)\end{array}$ & $\begin{array}{l}1.000 \\
0.960 \\
0.483\end{array}$ & $\begin{array}{l}0.001 \\
0.663 \\
0.000\end{array}$ & $\begin{array}{c}- \\
0.80-1.15 \\
0.33-0.72\end{array}$ & $\begin{array}{l}1.000 \\
1.068 \\
0.574\end{array}$ & $\begin{array}{c}- \\
0.532 \\
0.010\end{array}$ & $\begin{array}{c}- \\
0.87-1.31 \\
0.38-0.87\end{array}$ \\
\hline Household size & $\begin{array}{l}\leq 4(\mathrm{R}) \\
5-8 \\
9-11 \\
\leq 12\end{array}$ & $\begin{array}{c}1309(40.55) \\
1394(43.18) \\
277(8.58) \\
248(7.68)\end{array}$ & $\begin{array}{l}1.000 \\
1.002 \\
0.685 \\
0.404\end{array}$ & $\begin{array}{c}<0.001 \\
0.985 \\
0.005 \\
0.000\end{array}$ & $\begin{array}{c}- \\
0.86-1.17 \\
0.53-0.89 \\
0.31-0.53\end{array}$ & $\begin{array}{l}1.000 \\
0.945 \\
0.605 \\
0.333\end{array}$ & $\begin{array}{c}- \\
0.526 \\
0.010 \\
0.000\end{array}$ & $\begin{array}{c}- \\
0.79-1.13 \\
0.45-0.81 \\
0.24-0.45\end{array}$ \\
\hline Travel cost $t^{\circ}$ & $\begin{array}{l}\leq 3.90 \mathrm{GHC}(\mathrm{R}) \\
4.00-7.50 \mathrm{GHC} \\
\geq 7.60 \mathrm{GHC}\end{array}$ & $\begin{array}{c}2151(66.64) \\
894(27.70) \\
183(1.67)\end{array}$ & $\begin{array}{l}1.000 \\
0.592 \\
0.281\end{array}$ & $\begin{array}{c}<0.001 \\
0.000 \\
0.000\end{array}$ & $\begin{array}{c}- \\
0.51-0.69 \\
0.20-0.39\end{array}$ & $\begin{array}{l}1.000 \\
0.841 \\
0.407 \\
\end{array}$ & $\begin{array}{c}- \\
0.037 \\
0.000\end{array}$ & $\begin{array}{c}- \\
0.69-1.03 \\
0.28-0.58\end{array}$ \\
\hline SES & $\begin{array}{l}\text { Low }(\mathrm{R}) \\
\text { Middle } \\
\text { High }\end{array}$ & $\begin{array}{l}1874(58.05) \\
938(28.97) \\
419(12.98)\end{array}$ & $\begin{array}{l}1.000 \\
1.738 \\
2.136\end{array}$ & $\begin{array}{l}<0.001 \\
0.000 \\
0.000\end{array}$ & $\begin{array}{c}- \\
1.05-1.43 \\
1.22-1.89\end{array}$ & $\begin{array}{l}1.000 \\
1.467 \\
1.656\end{array}$ & $\begin{array}{c}- \\
0.000 \\
0.000\end{array}$ & $\begin{array}{c}- \\
1.21-1.77 \\
1.27-2.16\end{array}$ \\
\hline
\end{tabular}

$\mathrm{CI}$, confidence interval; SES, socioeconomic status. ${ }^{*} \mathrm{R}$ refers to the reference group used for comparison within each category; ${ }^{\circ} 1 \mathrm{GH} \mathrm{c}=\$ 0.67$ as at the time of the study. 
cal location, some household heads incur close to $10 \mathrm{GHC}$ to make a round trip, which can also include walking part of the journey to register. It will therefore be appropriate to use findings in studies like this to guide premium packages for location specific as an additional incentive for the rural poor. Scheme administrators should devise ways of reaching out to the remotest communities occasionally to register them right in their localities.

Indicators, such as occupation, marital status and religious beliefs, have no significant statistical effect in determining the enrollment of an entire household membership into the program as responses to such variables could vary among individuals even within the household unit. Policy decisions should focus on interventions directed generally at educating the masses such as the poor, younger household heads, large households, residents with low educational levels and those working outside of the formal service sector on the benefits of subscribing to the program using places such as churches, mosques and market centers.

\section{Strength and limitations}

A noticeable strength from this study is the fact it was done with a large but representative sample size that has never been studied within the BCCDP site in relation to complete household participation in the newly implemented national health insurance program. The research findings will therefore add to the knowledge base on the NHIS and will help inform policy decision with added perceptions from a typical rural setting on how best to achieve the primary goal of gaining universal coverage.

The limitations from the study, however, include the fact that findings from the analyses could be confounded by respondents' failure to recall requisite information asked of them. A classic example is the inability of some interviewees to recall or substantiate their correct dates of births with birth records when such information was required either on themselves or the dependents they represented. There were series of measurement problems that particularly hinder the use of income and expenditures measures in the participating communities due to lack of good record keeping practice and the fact that most of the residents do not earn regular income from the formal sector. This is principally the situation in the deprived nations of the world where wealth index are debatably most significant. ${ }^{29}$ The use of proxy measures as in our case was the best alternative, however it usage also comes with an associated weakness since the investigator has no better means of authenticating every response to ownership of a household assets.

Another notable limitation to this study was the fact that we did not ask about partial coverage in the NHIS within the respective households. Some households could have had a few, but not all, members enrolled. In such cases, the entire household membership was ruled out as not having complete health insurance coverage.

Finally, the trends observed during this evaluation still need to be confirmed with a larger sample size in longitudinal study over the time of several years to confidently extrapolate findings to the entire country.

\section{Conclusions}

Notwithstanding the steady increase in the enrollment patterns to the NHIS since its inception, it is worth pointing out that eight years down the road, it has not achieve its full coverage rate as stipulated in the implementing policy objective. Enrollment to the scheme is still conditioned on many factors of which the socioeconomic standing of the household, age, educational level attained by the household head, household size, and travel costs to the NHIS enrollment center are relevant. Increased effort to expand membership is critically needed if this benefit is to cover all Ghanaians. Since cost was found to be a major obstacle to enrollment, more effective methods for identifying citizens at risk for non-enrollment in NHIS for the purposes of premium exemption and discount are desirable. Besides the general low level of education, distance and cost to travel to the registration center hinders the ability of residents to subscribe or renew membership to the program.

It is appropriate for policy makers to consider implementing the recommended suggestions in localized settings in studies as this to help achieve the national and global effort in bridging the healthcare disparities in societies.

\section{Significance for public health}

By implementing the suggested recommendations from this project, the NHIS will be able to maximize its enrollment rate with rippling effects of getting the citizenry (especially the rural inhabitants) more access to legitimate healthcare, thereby helping to improve their quality of life.

\section{References}

1. Onwujekwe 0 , Onoka C, Uzochukwu B, et al. Is community-based health insurance an equitable strategy for paying for healthcare? Experiences from southeast Nigeria. Health Policy 2009;92:96-102.
2. Richard F, Hercot D, Ouédraogo C, et al. Sub-Saharan Africa and the health MDGs: the need to move beyond the "quick impact" model. Reprod Health Matters 2011;19:42-55.

3. Salisu A, Prinz V. Health care in Ghana; March 2009. Wien: Austrian Centre for Country of Origin \& Asylum Research and Documentation (ACCORD); 2009. Available from: http://www.ecoi.net/file upload/90_1236873017_accord-healthcare-in-ghana-20090312.pdf

4. Sulzbach S, Garshong B. Evaluating the effects of the National Health Insurance Act in Ghana: baseline report. Bethesda, MD: The Partners for Health Reformplus Project, Abt. Associate; 2005.

5. Brugiavini A, Pace N. Extending health insurance: effects of the National Health Insurance Scheme in Ghana. Development 2010;1:1-40. Available from: http://erd.eui. eu/media/BackgroundPapers/BrugiaviniPace-Extending\%20Healt\%20Insurance. pdf

6. Soors W, Devadasan N, Atim C. Community health insurance in developing countries. Community Health Workers 2008;6:782-91.

7. Hsiao WC, Shaw RP, Fraker A, et al. Social health insurance for developing nations. Washington, DC: The World Bank; 2007. Available from: http://www.hsph.harvard. edu/health-care-financing/files/2012/ 09/hsiao_and_shaw_2007_-_shi_for_ developing_nations.pdf

8. Dalinjong PA, Laar AS. The national health insurance scheme: perceptions and experiences of health care providers and clients in two districts of Ghana. Health Econ Rev 2012;2:13.

9. Asenso-Okyere WK. Cost recovery in Ghana: are there any changes in health care seeking behaviour? Health Policy Plan 1998;13:181-8.

10. Mante AA. An initial analysis of the effectiveness of Ghana's National Health Insurance Scheme on access to healthcare in the New Juaben Municipal District. Ph.D dissertation, Walden University, Minnesota. Ann Arbor, MI: UMI Dissertations Publishing; 2011. Available from: http:/search.proquest. com/docview/ 876012129 [Abstract].

11. Chankova S, Sulzbach S, Diop F. Impact of mutual health organizations: evidence from West Africa. Health Policy Plan 2008;23:264-76.

12. Bennett $\mathrm{S}$. The role of community-based health insurance within the health care financing system: a framework for analysis. Health Policy Plan 2004;19:147-58.

13. Agyepong IA, Adjei S. Public social policy development and implementation: a case study of the Ghana National Health 
Insurance Scheme. Health Policy Plan 2008;23:150-60.

14. McIntyre D, Gilson L, Mutyambizi V, et al. Promoting equitable health care financing in the African context: current challenges and future prospects. EQUINET discussion paper number 27. Harare: Regional Network for Equity in Health in Southern Africa (EQUINET); 2005. Available from: http://www.equinetafrica.org/bibl/docs/DIS 27fin.pdf

15. National Health Insurance Authority (NHIA). NHIS Annual Report 2010. Accra: NHIA; 2010. Available from: http://www. nhis.gov.gh/files/8(1).pdf

16. Sarpong N, Loag W, Fobil J, et al. National health insurance coverage and socio-economic status in a rural district of Ghana. Trop Med Int Health 2010;15:191-7.

17. Jehu-Appiah C, Aryeetey G, Spaan E, et al. Equity aspects of the National Health Insurance Scheme in Ghana: who is enrolling, who is not and why? Social Sci Med 2011;72:157-65.

18. Gilson L, Russell S, Buse K. The political economy of user fees with targeting: developing equitable health financing policy. $\mathrm{J}$ Int Develop 1995;7:369-401.

19. De Schweinitz P, Ansong D, Manortey S, et al. Evaluating international collaboration: differential perceptions of partnership in a CBPR project in Ghana. $\mathrm{J}$ Empirical Res Human Ethics 2009;4:53-67.

20. Crookston BT, Alder SC, Boakye I, et al. Exploring the relationship between chronic undernutrition and asymptomatic malaria in Ghanaian children. Malaria $\mathrm{J}$ 2010;9:39.

21. Manortey S, Carey A, Ansong D, et al. Verbal autopsy: an analysis of the common causes of childhood death in the Barekese sub-district of Ghana. J Public Health Africa 2011;2:e18.

22. Krakowiak-Redd D, Ansong D, Otupiri E, et al. Family Planning in a Sub-district near Kumasi, Ghana: side effect fears, unintended pregnancies and misuse of a medication as emergency contraception. Afr J Reprod Health 2011;15:135-48.

23. Filmer D, Pritchett L. Estimating wealth effects without expenditure data-or tears: an application to educational enrollments in states of India. Demography 2001;38:115-32.

24. Manthalu G, Nkhoma D, Kuyeli S. Simple versus composite indicators of socioeconomic status in resource allocation formulae: the case of the district resource allocation formula in Malawi. BMC Health Serv Res 2010;10:6.
25. Vyas S, Kumaranayake L. Constructing socio-economic status indices: how to use principal components analysis. Health Policy Plan 2006;21:459-68.

26. Seddoh A, Adjei S, Nazzar A. Ghana's National Health Insurance Scheme. Views on progress, observations and commentary. Accra: Centre for Health and Social Services; 2011. Available from: http://www.ch-ghana.org/documents/ Publication/Report\%20on\%20observations $\% 20$ and $\% 20$ commentary $\% 20$ on $\% 20 \mathrm{~N}$ HIS.pdf

27. Dixon J. Financing national health insurance in Ghana. Waterloo, ON: CIGI; 2011. Available from: http://dspace.cigilibrary. org/jspui/bitstream/123456789/31719/1/Ba ckgrounder\%20No.\%208.pdf?1

28. Onwujekwe 0, Onoka C, Uguru N, et al. Socio-economic and geographic differences in acceptability of community-based health insurance. Public Health 2011; 125:806-8.

29. Houweling TAJ, Kunst AE, Mackenbach JP. Measuring health inequality among children in developing countries: does the choice of the indicator of economic status matter? Int J Equity Health 2003;12:1-12. 